\title{
DOI: http://dx.doi.org/10.33846/sf11119
}

Penggunaan Kontrasepsi Hormonal dan Produksi Air Susu Ibu di Puskesmas Poasia

\author{
La Ode Alifariki \\ Departemen Epidemiologi, Fakultas Kedokteran, Universitas Halu Oleo; ners_riki@ yahoo.co.id (koresponden) \\ Adius Kusnan \\ Departemen Epidemiologi, Fakultas Kedokteran, Universitas Halu Oleo; adiuskusnan.fkuho@gmail.com \\ Ida Mardhia Afrini \\ Departemen Epidemiologi, Fakultas Kedokteran, Universitas Halu Oleo; idamardhia@gmail.com
}

\begin{abstract}
Breast milk is the best natural nutrient for babies because it contains energy needs and substances needed during the first six months of a baby's life. If during lactation the mother uses hormonal contraception, the lactation hormone namely the hormone prolactin and oxytocin will be suppressed so that the process of egg maturation immediately occurs, the mother immediately enters the fertile period and the milk production is disrupted. The purpose of this study was to determine the relationship between hormonal contraception and breast milk production in nursing mothers at Poasia Community Health Center, Kendari City in 2019. This type of research was analytic descriptive using a cross sectional approach. The population in this study was all mothers who breastfeeded at the Poasia Community Health Center in Kendari City in October to November as many as 70 with a sample of 41 respondents. The statistical test used was Chi square at $\alpha=0.05$. The results showed that most were using 3 types of 3-month injectable hormonal contraceptives (46.3\%), following the type of mini pills as many as 9 people (22.0\%), implants as many as 6 people (14.6\%), injecting 1 month as many as 5 people (12.2\%) and the least is using a combination pill of 2 people (4.9\%). The production of breast milk was 27 people (65.9\%) and the current category was 14 people (34.1\%). Statistical test results indicate that there was a relationship between the use of hormonal contraceptives and breast milk production in the work area of Poasia Community Health Center, Kendari City in 2019, with a p value of $0.004<0.05$.

Keywords: hormonal contraception; breast milk production; breastfeeding mothers
\end{abstract}

\begin{abstract}
ABSTRAK
ASI adalah nutrisi alami terbaik untuk bayi karena mengandung kebutuhan energi dan zat yang dibutuhkan selama enam bulan pertama kehidupan bayi. Jika selama menyusui ibu menggunakan kontrasepsi hormonal, hormone laktasi yaitu hormone prolaktin dan oksitosin akan ditekan sehingga proses pematangan telur segera terjadi, ibu segera memasuki masa subur dan produksi susu terganggu. Tujuan dari penelitian ini adalah untuk mengetahui hubungan antara kontrasepsi hormonal dan produksi ASI pada ibu menyusui di Pusat Kesehatan Masyarakat Poasia, Kota Kendari pada tahun 2019.Jenis penelitian ini adalah deskriptif analitik menggunakan pendekatan cross sectional. Populasi dalam penelitian ini adalah semua ibu yang menyusui di Pusat Kesehatan Masyarakat Poasia di Kota Kendari pada bulan Oktober hingga November sebanyak 70 dengan sampel 41 responden. Uji statistik yang digunakan adalah chi square pada $\alpha=0,05$. Hasil penelitian menunjukkan bahwa sebagian besar menggunakan 3 jenis kontrasepsi hormonal suntik 3 bulan (46,3\%), mengikutijenispil mini sebanyak 9 orang $(22,0 \%)$, implant sebanyak 6 orang (14,6\%), suntik 1 bulan sebanyak 5 orang $(12,2 \%)$ dan paling sedikitmenggunakanpilkombinasi 2 orang (4,9\%). Produksi ASI adalah 27 orang (65,9\%) dankategorisaatiniadalah 14 orang $(34,1 \%)$. Hasil uji statistic menunjukkan bahwa ada hubungan antara penggunaan kontrasepsi hormonal dan produksi ASI di area kerja Puskesmas Poasia, Kota Kendari pada tahun 2019, dengan nilai p 0,004<0,05.
\end{abstract}

Kata kunci: kontrasepsi hormon; produksi asi; ibu menyusui

\section{PENDAHULUAN}

Air Susu Ibu (ASI) merupakan nutrisi alamiah terbaik bagi bayi karena mengandung kebutuhan energi dan zat yang dibutuhkan selama enam bulan pertama kehidupan bayi. Seorang ibu sering mengalami masalah dalam pemberian ASI eksklusif, salah satu kendala utamanya yakni produksi ASI yang tidak lancar. Hal ini akan menjadi faktor penyebab rendahnya cakupan pemberian ASI eksklusif kepada bayi baru lahir ${ }^{(1)}$.

Bayi perlu menyusu sebanyak 8-12 kali dalam periode 24 jam. Pola menyusui bervariasi kerena setiap bayi berbeda. Beberapa bayi akan menyusu setiap 2-3 jam selama periode 24 jam. Bayi lainnya mungkin mempunyai pola kluster, yaitu menyusu setiap 3-4 jam diantaranya, 24-48 jam pertama setelah lahir, sebagian besar bayi tidak bangun sering ini untuk menyusu. Orang tua harus memahami bahwa mereka harus membangunkan bayi untuk menyusu minimal setiap 3 jam pada siang hari dan setiap 4 jam pada malam hari. 
Frekuensi menyusui ditentukan dengan menghitung awal dari satu sesi ke berikutnya. Dengan pola ini bayi harus mendapat minimal 8 kali sesi menyusui dalam $24 \mathrm{jam}^{(2)}$.

Idealnya, selama menyusui wanita menggunakan mini pil kontrasepsi yang hanya mengandung progesteron saja ${ }^{(3)}$. Pil $\mathrm{Kb}$ yang hanya mengandung progesteron saja dengan dosis rendah tidak memounyai dampak pada produksi ASI sehingga pilihan yang tepat bagi ibu yang sedang menyusui. Beberapa penelitian menunjukkan bahwa Pil KB yang mengandung progesteron dan estrogen dapat mencemari ASI sehingga dapat mempengaruhi kelancaran dan produksi $\mathrm{ASI}^{(4)}$.

Pemakaian kontrasepsi pasca melahirkan di Indonesia masi dianggap belum optimal, padahal kontrasepsi pasca melahirkan meningkatkan kesehatan ibu dan bayi dengan memperpanjang jarak kelahiran ${ }^{(5)}$.

Penggunaan kontrasepsi telah meningkat di banyak bagian dunia, terutama di Asia dan Amerika Latin dan terendah di Sub-Sahara Afrika. Secara global, pengguna kontrasepsi modern telah meningkat tidak signifikan dari 54\% pada tahun 1990 menjadi $57,4^{(6)}$. Secara regional, proporsi pasangan usia subur $15-49$ tahun melaporkan penggunaan metode kontrasepsi modern telah meningkat minimal 6 tahun terakhir. Di Afrika dari 23,6\% menjadi 27,6\%, di Asia telah meningkat dari 60,9\% menjadi 61,6\%, sedangkan Amerika latin dan Karibia naik sedikit dari $66,7 \%$ menjadi $67,0 \%{ }^{(7)}$. Diperkiraan 225 juta perempuan di negara-negara berkembang ingin menunda atau menghentikan kesuburan tapi tidak menggunakan metode kontrasepsi apapun dengan alasan sebagai berikut: terbatas pilihan metode kontrasepsi dan pengalaman efek samping ${ }^{(8)}$. Kebutuhan yang belum terpenuhi untuk kontrasepsi masih terlalu tinggi. Ketidakadilan didorong oleh pertumbuhan populasi.

Data Badan Kependudukan dan Keluarga Berencana Nasional (BKKBN) pada tahun 2013 mendapatkan 8.500.247 PUS (Pasangan Usia Subur) yang merupakan peserta KB baru, dengan rincian pengguna kontrasepsi suntik 4.128.115 peserta $(48,56 \%)$, pil 2.261 .480 peserta $(26,60 \%)$, implan 784.215 peserta $(9,23 \%)$, kondom 517.638 peserta $(6,09 \%)$, alat kontrasepsi dalam rahim 658.632 peserta $(7,75 \%)$, MOW (metode operasi wanita) 128.7932 peserta $(1,52 \%)$, MOP (metode operasi pria) 21.374 peserta $(0,25 \%)$, dari data diatas dapat kita lihat metode kontrasepsi suntik adalah metode yang terbanyak yang digunakan (9). Jika mengacu pada target Renstra Kementrian Kesehatan tahun 2016 sebesar 82\% untuk peserta KB aktif, Provinsi Sulawesi Tenggara masih jauh dari target dengan pencapaian hanya $61,05 \%{ }^{(9)}$.

Berdasarkan penelitian terdahulu yang berjudul Kajian Penggunaan Kontrasepsi Hormonal dengnan Lama Menyusui oleh Indrawati, bahwa lama ibu menyusui memiliki hubungan yang erat dengan penggunaan kontrasepsi hormonal. Dalam jurnal tersebut dijelaskan, beberapa metode kontrasepsi hormonal yang dapat menurunnkan kadar produksi air susu ibu(ASI) seperti pil kombinasi atau injeksi tiap bulan yang berisi estrogen dan progesteron, sehingga selama ibu menyusui sebaiknya menghindari kontrasepsi hormonal tersebut.

Pada masa menyusui (laktasi) hormon prolaktin dan oksitosin meningkat. Hormon prolaktin berfungsi memproduksi ASI sehingga mengisi alveoli sedangkan hormon oksitosin bekerja memeras ASI dari alveoli sehingga ASI disekresi ${ }^{(10)}$. Dalam keadaan fisiologis setelah menstruasi hari ke- 5 hormon FSH akan meningkat sehingga folikel matang. Namun pada masa laktasi, tingginya hormon prolaktin dan oksitosin akan memberikan umpan balik negatif terhadap hormon FSH (Follicle Stimulating Hormone) dan LH (Luteinizing Hormone) sehingga proses pematangan sel telur tidak terjadi ${ }^{(11)}$. Apabila pada masa laktasi ibu menggunakan kontrasepsi hormonal, maka hormon laktasi yaitu hormon prolaktin dan oksitosin akan ditekan sehingga proses pematangan sel telur segera terjadi, ibu segera masuk pada masa subur dan produksi ASI terganggu ${ }^{(11)}$.

Berdasarkan data dari Puskesmas Poasia Kota Kendariibu penggunaKB pada tahun 2017 sebanyak 3120 di antaranya menggunakan AKDR (396), MOP (6), MOW (69), Implat (482), kondom (128), pil (920), dan di dominasi dengan suntik sebanyak (1089), pada peserta $\mathrm{Kb}$ hormonal Didapati ibu menyusui dengan keluhan produksi ASI berkurang. Pada bulan oktober sampai november sebanyak 70 peserta KB diantaranya ibu yang menyusui menggunakan kontrasepsi hormonal 18 dan ibu yang tidak menyusui menggunakan kontrasepsi non hormonal 52 .

Berdasarkan fenomena tersebut peneliti tertarik untuk melakukan penelitan "Hubungan Penggunaan Alat Kontrasepsi Hormonal dengan Produksi ASI Pada Ibu Menyusui di Puskesmas Poasia Kota Kendari”

\section{METODE}

Jenis penelitian ini adalah penelitian deskriptif observasional, menggunakan metode cross sectional. Populasi penelitian ini adalah seluruh ibu menyusui di Puskesmas Poasia Kota Kendari pada bulan Juni 2019 sebanyak 70 orang dengan jumlah sampel 41 responden. Variabel penelitian adalah penggunaan alat kontrasepsi hormonal sebagai variabel independen sedangkan variabel dependen adalah produksi ASI. Alat ukur variabel adalah kuesioner berupa pertanyaan terstruktur. Uji statistik yang digunakan adalah Chi square dengan nilai kemaknaan $\alpha=0,05$. 


\section{HASIL}

\section{Karakteristik Responden}

Tabel 1. Distribusi karakteristik responden

\begin{tabular}{|c|c|c|}
\hline Karakteristik & Frekuensi & Persentase \\
\hline \multicolumn{3}{|l|}{ Umur (Tahun) } \\
\hline - $<20$ & 7 & 17,0 \\
\hline - $20-35$ & 25 & 61,0 \\
\hline - $>35$ & 9 & 22,0 \\
\hline \multicolumn{3}{|l|}{ Tingkat pendidikan } \\
\hline - $\mathrm{SD}$ & 1 & 2,4 \\
\hline - $\quad$ SMP & 13 & 31,7 \\
\hline - $\quad$ SMA & 21 & 51,2 \\
\hline $\begin{array}{ll}\text { - } & \text { Perguruan } \\
& \text { Tinggi }\end{array}$ & & 14,7 \\
\hline \multicolumn{3}{|l|}{ Jenis pekerjaan } \\
\hline - IRT & 37 & 90,2 \\
\hline - $\mathrm{PNS}$ & 2 & 4,9 \\
\hline - Swasta & 2 & 4,9 \\
\hline \multicolumn{3}{|l|}{ Status paritas } \\
\hline - $<3$ & 27 & 65,9 \\
\hline - $\quad \geq 3$ & 14 & 34,1 \\
\hline
\end{tabular}

Tabel 2 menunjukkan bahwa dari 41 responden yang paling banyak berdasarkan umur adalah berumur 20-35 tahun yaitu 25 orang $(61,0 \%)$ dan yang paling sedikit adalah usia $<20$ tahun sebanyak 7 orang $(17,0 \%)$. Tingkat pendidikan yang paling banyak adalah SMA sebanyak 21 orang $(51,6 \%)$ dan yang paling sedikit adalah tingkat pendidikan SD sebanyak 1 orang $(2,4 \%)$. Jenis pekerjaan yang paling banyak adalah jenis pekerjaan sebagai Ibu rumah tangga sebanyak 37 orang $(90,2 \%)$ dan yang paling sedikit adalah pegawai negeri sipil dan swasta sebanyak 2 orang $(4,9 \%)$. Status paritas $<3$ orang sebanyak 27 orang $(65,9 \%)$ dan yang paling sedikit adalah memiliki status paritas $\geq 3$ sebanyak 14 orang $(34,1 \%)$.

\section{Hasil Pengujian Hipotesis}

Tabel 2. Hubungan antara penggunaan kontrasepsi hormonal dengan produksi ASI

\begin{tabular}{|c|c|c|c|c|c|c|c|}
\hline \multirow{2}{*}{$\begin{array}{c}\text { Penggunaan Alat } \\
\text { Kontrasepsi Hormonal }\end{array}$} & \multicolumn{4}{|c|}{ Produksi ASI } & \multicolumn{2}{|c|}{ Total } & \multirow{2}{*}{$\begin{array}{c}\text { Nilai } \\
\text { Likelihood Ratio }\end{array}$} \\
\cline { 2 - 7 } & \multicolumn{2}{|c|}{ Lancar } & \multicolumn{2}{|c|}{ Tidak lancar } & \multicolumn{2}{|c|}{} \\
\cline { 2 - 7 } & $\mathrm{n}$ & $\%$ & $\mathrm{n}$ & $\%$ & $\mathrm{n}$ & $\%$ & \\
\hline Pil mini & 5 & 12,2 & 4 & 9,8 & 9 & 22,0 & \\
\hline Pil kombinasi & 1 & 2,4 & 1 & 2,4 & 2 & 4,9 & $\mathrm{p}=0,004$ \\
\hline Suntik 1 bulan & 0 & 0,0 & 5 & 12,2 & 5 & 12,2 & \\
\hline Suntik 3 bulan & 3 & 7,3 & 16 & 39,0 & 19 & 46,3 & \\
\hline Implan & 5 & 12,2 & 1 & 2,4 & 6 & 14,6 & \\
\hline Total & 14 & 34,1 & 27 & 65,9 & 41 & 100 & \\
\hline
\end{tabular}

Tabel 2 menunjukkan bahwa dari 41 responden yang paling banyak adalah menggunakan jenis alat kontrasepsi hormonal suntik 3 bulan sebanyak 19 orang (46,3\%) dan yang paling sedikit adalah menggunakan pil kombinasi sebanyak 2 orang (4,9\%). Produksi lancar pada ibu yang menggunakan hormonal jenis pil mini dan implant sebesar 12,2\% sedangkan produksi ASi tidak lancar pada hoemonal suntik 3 bulan sebesar 39\%. Hasil uji statistik menunjukkan bahwa nilai likelihood ratio $=0,004)$, artinya bahwa ada hubungan antara penggunaan alat kontrasepsi hormonal dengan produksi ASI di Wilayah kerja Puskesmas Poasia Kota Kendari.

\section{PEMBAHASAN}

Umur yang terbaik bagi seorang wanita adalah antara 20-30 tahun karena pada masa inilah alat-alat reproduksi wanita sudah siap dan cukup matang untuk mengandung dan melahirkan anak. Pada penelitian ini, memang akseptor KB yang menjadi responden dominan berusia antara 20-35 tahun. 
Pada penelitian tersebut didapati perempuan yang berusia lebih dari 30 tahun lebih banyak memilih menggunakan implan. Usia berpengaruh terhadap pemilihan alat kontrasepsi, semakin bertambah usia istri maka pemilihan alat kontrasepsi yang memiliki tingkat efektifitas lebih tinggi yaitu menggunakan metode kontrasepsi jangka panjang. Jenis kontrasepsi harus mempertimbangkan usia akseptor, bila usia lebih dari 35 tahun maka lebih efektif menggunakan metode kontrasepsi jangka panjang ${ }^{(12)}$.

Jumlah anak merupakan salah satu faktor yang paling mendasar mempengaruhi perilaku PUS dalam menggunakan kontrasepsi ${ }^{(13)}$. Sejalan dengan konsep Selogan "dua anak lebih baik", BKKBN memprioritaskan penggunaan kontrasepsi implan sebagai metode kontrasepsi jangka panjang yang efektif dalam mengendalikan jumlah penduduk ${ }^{(14)}$. Pada penelitian ditemukan bahwa dominan ibu yang telah mempunyai anak 3 atau lebih lebih memilih alat kb implan.

Saat ini di tengah-tengah masyarakat masih ada yang menganut konsep tradisional, yaitu cenderung memilih untuk memiliki anak dalam jumlah yang banyak. Dalam penelitian ini pula didapatkan data bahwa dominan responden memiliki anak lebih dari 2 orang sehingga dapat disimpulkan bahwa masyarakat tidak mengindahkan anjuran BKKBN yakni 2 anak cukup karena mereka masih berprinsip bahwa banyak anak, banyak rejeki dan apabila mempunyai banyak anak dapat membantu orang tua dalam mencari tambahan pendapatan orang tua.

Pada hasil penelitian ini, dapat disimpulkan bahwa responden yang memiliki pendidikan tinggi lebih banyak memilih kontrasepsi implan untuk mencegah kehamilan. Hasil penelitian menunjukkan bahwa dari 6 responden yang memilih impan ada 3 berpendidikan tinggi (Diploma dan Sarjana) dan hanya 3 orang berpendidikan SMA.

Sejalan dengan penelitian Safitri I (2016) yang menyatakan bahwa dominan yang menggunakan kontrasepsi hormonal adalah berpendidikan tinggi yakni SMA dan Sarjana ${ }^{(15)}$.

Produksi Air susu ibu/Prolaktin, dalam fisiologi laktasi,prolaktin merupakan Hormon yang disekresi oleh glandula pituitari.Hormon ini memiliki peranan penting untuk memproduksi ASI, kadar hormon ini meningkat selama kehamilan .kerja hormon ini dihambat oleh hormon plasenta.dengan lepas atau keluarnya keluarnya plasenta pada ahir proses persalinan, maka kadar estrogen dan progesteron berangsur-angsur menurun sampai tingkat dapat dilepaskan dan diaktifkan prolaktin. peningkatan kadar prolaktin akan menghambat ovulasi, dan dengan demikian juga mempunyai fungsi kontrasepsi.

Hasil penelitian menunjukkan bahwa responden yang menggunakan KB jenis pil mini sebanyak 9 orang $(22,0 \%)$ dan ada 66,7\% yang memiliki produksi ASI lancar. Dominan responden yang memakai KB pil mini, memiliki produksi ASI yang lancar, hal ini disebabkan karena KB pil mini, hanya mengandung progesterone yang mana hormone ini tidak menekan kerja hormone prolactin sehingga produksi ASI tidak berkurang.

Lain halnya dengan penggunaan alat KB pil kombinasi, dalam penelitian ini ada 2 responden yang memakai KB pil kombinasi dan terlaporkan bahwa memiliki produksi ASI yang kurang. Studi tentang menyusui yang dilakukan Hannon dkk (1997) mendukung temuan Manan menunjukkan wanita yang mendapatkan medroxyprogesterone rata-rata lama menyusui lebih lama dibandingkan wanita yang menggunakan kontrasepsi non hormonal ${ }^{(16)}$. Kontrasepsi hormonal yang berisi progesterone saja seperti mini pill, Depo medroxy progesterone dan Implan tidak berpengaruh terhadap kualitas dan kuantitas ASI dan justru dapat meningkatkan volume ASI dibanding kontrasepsi non hormonal ${ }^{(16)}$.

Sejalan pula dengan penelitian Safitri I (2016) yang menyatakan bahwa ada pengaruh antara penggunaan alat kontrasepsi terhadap kelancaran produksi ASI di Desa Bendan, Kecamatan Banyudono, Kabupaten Boyolali (nilai $\mathrm{p}=0,022<0,05$ ). Dalam penelitiannya Safitri I menemukan penggunaan kontrasepsi kombinasi hormon estrogen dan progesteron berkaitan dengan penurunan volume dan durasi ASI, sebaliknya bila kontrasepsi hanya mengandung progesteron maka tidak ada dampak terhadap volume ASI ${ }^{(15)}$

Didukung pula hasil penelitian Purwaningsih E dan Rita (2011) yang menyatakan bahwa ada pengaruh pemakaian kontrasepsi suntik dengan pengeluaran ASI dengan $\chi^{2}$ hitung $=6,399$, df $=1 \chi^{2}$ tabel 3,84 dengan nilai $\mathrm{p}=0,011(\mathrm{p}<0,05)^{(17)}$.

Hasil penelitian tentang hubungan penggunaan alat kontrasepsi hormonal dengan produksi ASI, diperoleh bahwa dari 9 responden yang tidak menggunakan alat hormonal pil mini, lebih banyak yang memiliki produksi ASI lancar sebanyak 5 orang $(12,2 \%)$ dan tidak lancar hanya 4 orang $(9,8 \%)$. Hal ini disebabkan karena kandungan pilmini adalah hormon progesterone yang dapat merangsang produksi ASI. Akan sama halnya dengan 2 responden yang menggunakan pil kombinasi, ada 1 orang $(2,4 \%)$ memiliki ASI lancar dan 1 orang $(2,4 \%)$ tidak lancar. Hal ini disebabkan pula karena kandungan pil kombinasi adalah gabungan antara hormone estrogen yang sifatnya menghambat produksi ASI dan sebaliknya progesterone melancarkan produksi ASI.

Dari 41 responden yang menggunakan alat kontrasepsi hormonal, lebih banyak yang memiliki produksi ASI tidak lancar sebanyak 27 orang $(65,9 \%)$ dan lancar ada 14 orang $(34,1 \%)$. Hal ini disebabkan karena beberapa responden menggunakan jenis kontrasepsi yang mengandung progesterone dan ekstrogen dan dapat disebabkan karena faktor lain di luar penelitian seperti tidak melakukan perawatan payudara selama hamil, ada gangguan pada saluran ASI ibu, dan faktor psikologi ibu. 
Bagi Ibu yang dalam masa menyusui, tidak dianjurkan menggunakan kontrasepsi suntikan yang mengandung estrogen karena hal ini dapat menurunkan jumlah produksi ASI, sehingga dapat menurunkan kelancaran pengeluaran ASI Selama masa laktasi. Kadar estrogen yang tinggi pada kontrasepsi dapat menekan FSH, sehingga merangsang lobus anterior hipofise untuk mengeluarkan luteinising hormone. Produksi luteinising hormone ini di bawah pengaruh releasing hormone yang disalurkan dan hipotalamus ke hipofisis. Adanya sekresi luteinising hormone, maka dapat menyebabkan hipotalamus untuk melepas faktor penghambat prolaktin (PIF) yang dianggap sebagai dopamin. Dopamin ini dapat menurunkan sekresi prolaktin sampai sepuluh kali lipat. Bila sekresi prolaktin dihambat, maka sel-sel alveoli pada payudara tidak akan memproduksi air susu. Dengan tidak adanya produksi air susu, maka pengeluaran ASI juga terhambat.

Hasil cross tabulasi data diperoleh bahwa ada beberapa responden yang memiliki produksi ASI tidak lancar meskipun menggunakan suntik 3 bulan, pil mini dan implant. Hal ini dapat dipengaruhi oleh faktor psikologi ibu. Hasil wawancara dengan beberapa ibu ditemukan adanya ibu yang khawatir ASI nya tidak cukup untuk memenuhi kebutuhan bayinya.

Faktor yang dapat menghambat produksi oksitosin adalah perasaan takut, cemas, sedih, marah, kesal (Rusli, 2008 dan Soetjiningsih, 2005). Bila ibu stress atau cemas maka akan terjadi suatu hambatan dari let down refleks. Hal tersebut terjadi karena adanya pelepasan epinefrin yang menyebabkan vasokontriksi dari pembuluh darah alveoli, sehingga oksitosin terhambat untuk mencapai target organ yaitu mioepitelium. Akibat dari let down refleks yang tidak sempurna menyebabkan aliran ASI tidak maksimal yang menyebabkan bendungan ASI dan akhirnya akan menghambat hormon prolaktin untuk memproduksi ASI.

Hasil penelitian ini sejalan dengan penelitian Dewey (2001) yang menunjukkan bahwa ibu-ibu dengan seksio sesarea akan mengalami hambatan dalam memberikan ASI dikarenakan oleh faktor kecemasan ibu terhadap kondisinya maupun kondisi bayi dan sebanyak $63 \%$ ibu memutuskan untuk memberikan susu formula karena ASI-nya tidak keluar. Didukung pula hasil penelitian Nurliawati (2010) yang menyatakan bahwa salah satu faktor yang berhubungan dengan produksi ASI adalah kecemasan ( $\mathrm{p}$ value $=0,003$ ).

Adanya responden atau ibu menyusui yang memiliki produksi ASI lancar meskipun menggunakan kontrasepsi jenis suntik 1 bulan dan pil kombinasi, karena rutin melakukan perawatan payudara setelah melahirkan. Hasil wawancara dengan beberapa ibu diperoleh informasi bahwa responden rutin melakukan perawatan payudara atas saran Bidan saat melahirkan. Sejalan dengan penelitian Yuliasari (2014) yang menyatakan penggunaan KB pil kombinasi berpengaruh terhadap produksi ASI, dalam penelitian ini diperoleh sebanyak 31,1\% ibu yang tidak mengkonsumsi KB pil kombinasi namun produksi ASI kurang baik, hal ini disebabkan oleh makanan, dan perawatan payudara ${ }^{(18)}$.

Sejalan dengan hasil penelitian Scholichah (2012), menunjukkan hasil bahwa ada hubungan antara perawatan payudara pada ibu post partum dengan kelancaran pengeluaran ASI diperoleh dari $(p=0,007)$. Hasil penelitian ini diperkuat dengan hasil penelitian Djumadi, dkk (2014), menyatakan bahwa ada hubungan antara perawatan payudara dengan produksi ASI pada ibu primipara $(\mathrm{p}=0,002)^{(19)}$.

Sejalan dengan teori bahwa peran bidan dalam pengeluaran ASI adalah memberikan pendidikan kesehatan tentang perawatan payudara. Nuryantini mendefinisikan perawatan payudara adalah perawatan payudara ibu setelah melahirkan. Perawatan payudara pada masa nifas dapat melenturkan dan menguatkan puting susu, merangsang pengeluaran ASI serta menjaga kebersihan payudara, terutama puting susu. Perawatan payudara dapat dilakukan pada $1-3$ hari post partum.

Hasil uji statistik menunjukkan bahwa ada hubungan antara penggunaan alat kontrasepsi hormonal dengan produksi ASI di Wilayah kerja Puskesmas Poasia. Hasil penelitian ini sejalan dengan penelitian Endah Purwaningsih dan Rita S (2011) yang menyatakan bahwa ada pengaruh pemakaian kontrasepsi suntik dengan pengeluaran ASI di Bidan Praktek Swasta Tri Paryati Kemalang Kemalang Kabupaten Klaten. dengan $\chi 2$ hitung $=6,399, \mathrm{df}=1 \chi 2$ tabel 3,84 dengan nilai $\mathrm{p}=0,011(\mathrm{p}<0,05)^{(17)}$.

Sejalan pula dengan penelitian yang dilakukan oleh Dewi Yuliasari (2014) yang menyatakan bahwa ada hubungan penggunaan KB Pil dengan produksi ASI pada ibu menyusui di Wilayah Kerja Puskesmas Bernung Kabupaten Pesawaran Tahun 2014 dengan nilai $p$ value $0,023<\alpha 0,05^{(18)}$.

Didukung pula oleh hasil penelitian Indarwati (20(16)09) tentang Kajian Penggunaan Kontrasepsi Hormonal dengan Lama Ibu Menyusui di Sukoharjo. Dimana hasil penelitiannya menunjukkan bahwa terdapat hubungan antara penggunaan kontrasepsi hormonal dengan lama ibu menyusui dengan $p=0.002$ Probabilitas ibu untuk menyusui hingga paling sedikit umur dua tahun atau lebih, lebih besar

\section{KESIMPULAN}

Kesimpulan penelitian yakni ibu yang memakai kontrasepsi hormonal mengandung ekstrogen dominan menghambat produksi ASI dan sebaliknya hormonal mengandung progesterone meningkatkan produksi ASI.

\section{DAFTAR PUSTAKA}

1. Wulandari, Handayani. Asuhan Kebidanan Ibu Masa Nifas. Yogyakarta: Gosyen Publishing; 2011. 
2. Wiji. ASI dan Panduan Ibu Menyusui. Yogyakarta: Nuha Medika; 2013.

3. Hall KS, Trussell J, Schwarz EB. Progestin-only contraceptive pill use among women in the United States. $\begin{array}{lllll}\text { Contraception [Internet]. 2012/06/06. } 2012 & \text { Dec;86(6):653-8. Available from: }\end{array}$ https://www.ncbi.nlm.nih.gov/pubmed/22682722

4. Espey E, Ogburn T, Leeman L, Singh R, Ostrom K, Schrader R. Effect of progestin compared with combined oral contraceptive pills on lactation: a randomized controlled trial. Obstet Gynecol [Internet]. 2012 Jan;119(1):5-13. Available from: https://www.ncbi.nlm.nih.gov/pubmed/22143258

5. Wilopo SA, Setyawan A, Pinandari AW, Prihyugiarto T, Juliaan F, Magnani RJ. Levels, trends and correlates of unmet need for family planning among postpartum women in Indonesia: 2007-2015. BMC Womens Health [Internet]. 2017 Nov 28;17(1):120. Available from: https://www.ncbi.nlm.nih.gov/pubmed/29179744

6. Najafi-Sharjabad F, Zainiyah Syed Yahya S, Abdul Rahman H, Hanafiah Juni M, Abdul Manaf R. Barriers of modern contraceptive practices among Asian women: a mini literature review. Glob J Health Sci [Internet]. $2013 \mathrm{Jul}$ 22;5(5):181-92. Available from: https://www.ncbi.nlm.nih.gov/pubmed/23985120

7. Ochako RA. Patterns of Contraceptive Use among Vulnerable Populations in Kenya [Internet]. Ghent University; 2018. Available from: http://icrh.org/sites/default/files/thesis submitted to bibio.pdf

8. Endriyas M, Eshete A, Mekonnen E, Misganaw T, Shiferaw M. Where we should focus? Myths and misconceptions of long acting contraceptives in Southern Nations, Nationalities and People's Region, Ethiopia: qualitative study. BMC Pregnancy Childbirth [Internet]. 2018;18(1):98. Available from: https://doi.org/10.1186/s12884-018-1731-3

9. $\quad$ RI K. Rencana Aksi Nasional Pelayanan Keluarga Berencana. Jakarta; 2016.

10. Augustine RA, Ladyman SR, Bouwer GT, Alyousif Y, Sapsford TJ, Scott V, et al. Prolactin regulation of oxytocin neurone activity in pregnancy and lactation. J Physiol [Internet]. 2017/03/23. 2017 Jun 1;595(11):3591-605. Available from: https://www.ncbi.nlm.nih.gov/pubmed/28211122

11. Jannah A. Gambaran Tingkat Pengetahuan Ibu Nifas tentang Kontrasepsi Metode Amenore Laktasi (MAL) [Internet]. 2014. Available from: http://digilib.stikeskusumahusada.ac.id/files/disk1/12/01-gdl-yuniseniwa594-1-b11059y-i.pdf

12. Amran Y, Nasir NM, Dachlia D, Yelda F, Utomo B, Ariawan I, et al. Perceptions of Contraception and Patterns of Switching Contraceptive Methods Among Family-planning Acceptors in West Nusa Tenggara, Indonesia. J Prev Med Public Heal [Internet]. 2019 Jul 19;52(4):258-64. Available from: https://doi.org/10.3961/jpmph.18.198

13. Solanke BL. Factors influencing contraceptive use and non-use among women of advanced reproductive age in Nigeria. J Health Popul Nutr [Internet]. 2017 Jan 7;36(1):1. Available from: https://www.ncbi.nlm.nih.gov/pubmed/28061805

14. Jurisman, Ariadi K. Hubungan Karakteristik Ibu dengan Pemilihan Kontrasepsi diPuskesmas Padang Pasir Padang. J Kesehat Andalas. 2016;5(1):191-5.

15. Safitri I. Pengaruh penggunaan alat kontrasepsi terhadap kelancaran produksi ASI di Desa Bendan, Kecamatan Banyudono, Kabupaten Boyolali. 2016;

16. Indarwati. Kajian Penggunaan Kontrasepsi Hormonal dengan Lama Ibu Menyusui di Sukoharjo. 2009;

17. Purwaningsih dan Rita S. Pengaruh Kontrasepsi Suntik Terhadap Pengeluaran ASI Eksklusif di BPS Triparyati Kemalang Kemalang Kabupaten Klaten. J Involusi Kebidanan. 2011;1(1):9-19.

18. Yuliasari. Hubungan Penggunaan Kb Pil Kombinasi Dengan Produksi ASI Pada Ibu Menyusui di Puskesmas Bernung Kabupaten Pesawaran Tahun 2014. J Holistik. 2014;9(4):183-6.

19. Scholichah. Hubungan Antara Perawatan Payudara Pada Ibu Post Partum Dengan Kelancaran Pengeluaran ASI, Sinar Harapan. 2012; 